\title{
Non-native habitat as home for non-native species: comparison of communities associated with invasive tubeworm and native oyster reefs
}

\author{
Kimberly W. Heiman ${ }^{1,2, *}$, Nicholas Vidargas ${ }^{1}$, Fiorenza Micheli ${ }^{1}$ \\ ${ }^{1}$ Stanford University, Hopkins Marine Station, 100 Oceanview Boulevard, Pacific Grove, California 93950, USA \\ ${ }^{2}$ Present address: Oregon State University, Department of Zoology, 3029 Cordley Hall, Corvallis, Oregon 97331, USA
}

\begin{abstract}
Introduction vectors for marine non-native species, such as oyster culture and boat fouling, often select for organisms dependent on hard substrates during some or all life stages. In softsediment estuaries, hard substrate is a limited resource, which can increase with the introduction of hard habitat-creating non-native species. Positive interactions between non-native, habitat-creating species and non-native species utilizing such habitats could be a mechanism for enhanced invasion success. Most previous studies on aquatic invasive habitat-creating species have demonstrated positive responses in associated communities, but few have directly addressed responses of other nonnative species. We explored the association of native and non-native species with invasive habitatcreating species by comparing communities associated with non-native, reef-building tubeworms Ficopomatus enigmaticus and native oysters Ostrea conchaphila in Elkhorn Slough, a central California estuary. Non-native habitat supported greater densities of associated organisms-primarily highly abundant non-native amphipods (e.g. Monocorophium insidiosum, Melita nitida), tanaid (Sinelebus sp.), and tube-dwelling polychaetes (Polydora spp.). Detritivores were the most common trophic group, making up disproportionately more of the community associated with $F$. enigmaticus than was the case in the $O$. conchaphila community. Analysis of similarity (ANOSIM) showed that native species' community structure varied significantly among sites, but not between biogenic habitats. In contrast, non-natives varied with biogenic habitat type, but not with site. Thus, reefs of the invasive tubeworm $F$. enigmaticus interact positively with other non-native species.
\end{abstract}

KEY WORDS: Ficopomatus enigmaticus · Ostrea conchaphila · Elkhorn Slough · Biological invasion · Biogenic habitat $\cdot$ Invasion meltdown $\cdot$ Non-native species $\cdot$ Introduced species

\section{INTRODUCTION}

Invasive species are a major threat to terrestrial and an increasing threat to marine biodiversity (Wilcove et al. 1998, Kappel 2005). One of the key factors affecting the establishment and subsequent population growth of non-native and invasive species is the presence of necessary resources (such as food, living space, and light for photosynthetic organisms) in their recipient environment. An increase in the availability of limited resources will likely reduce an ecosystem's resistance to the establishment of non-native species (Davis et al.
2000, Davis \& Pelsor 2001). Davis's hypothesis is based on the assumption that non-native species need certain resources, and their establishment success will be enhanced if they gain access to those resources (Davis et al. 2000). Resource availability can be enhanced by a decrease in the resident community's use of the resource or by an increase in the resource supply.

Several major marine species introduction vectors, such as boat fouling, rock ballast, and aquaculture of bivalves, particularly oysters, select for organisms that utilize hard substrates (Carlton 1996, Wonham \& Carlton 2005). Many highly invaded marine ecosystems 
(bays, estuaries, lagoons and ocean inlets) are softsediment environments, with limited amounts of naturally occurring hard substrates. Thus, suitable hard substrates in the recipient environments are a limiting resource for non-native species. Anthropogenically derived hard substrates within these invaded marine ecosystems have increased via structural additions associated with the construction of seawalls, harbors, docks and bridges.

An additional mechanism of hard substrate addition is through the introduction of non-native species that create habitat (e.g. bivalves, tubeworms, and submerged and marsh vegetation). Species that create habitats are most commonly referred to as 'foundation species' (Dayton 1972, Ellison et al. 2005) or 'ecosystem engineers' (Jones et al. 1994, 1997), and are defined as species that structure communities by creating locally stable conditions for other species and by modulating and stabilizing fundamental ecosystem processes (Ellison et al. 2005). Ecosystem engineers are critical components of, and defining organisms in, a wide range of ecosystems, including terrestrial temperate and tropical forests, coral reefs, and kelp forests. However, when non-native species invade an ecosystem and create new structural habitats, they can affect community composition and fundamental ecosystem processes such as nutrient cycling, resource availability and resilience to disturbances (references in Table 1).

Positive interactions with non-native, habitat-forming species may enhance the establishment and population growth of other non-native species that utilize the biogenic habitat. This process is an example of an 'invasional meltdown,' in which non-native species facilitate ongoing and subsequent invasions by increasing survival, population size, or the magnitude or extent of ecological impacts of other non-native species (Simberloff \& Von Holle 1999).

Many researchers have examined community responses associated with the introduction of aquatic ecosystem engineers. The exemplary studies in Table 1 show that most individual species or communities have positive responses (i.e. increases in abundance, diversity, or biomass) or a mix of positive and negative responses to the presence of introduced aquatic ecosystem engineers. Only non-native marsh plants, which simultaneously displace native plants and greatly reduce the quality and availability of mud habitat for infaunal species, have overall negative effects. Few studies examined the effects of non-native habitat on associated non-native species-but see Stewart et al. (1998), showing increases in abundance of a single non-native species; Balata et al. (2004), finding a mix of positive and negative responses varying with species and location; Wonham et al. (2005), observing the positive responses of 4 non-natives. The lack of information on non-native responses to the invasion of biogenic species could be due to a lack of associated non-native species or because the authors did not ask this specific question. In either case, the question of whether non-native biogenic habitats facilitate associated non-native species and provide a mechanism for invasional meltdown is largely unanswered.

In the present study, we explored this issue by comparing communities associated with the non-native, reef-building serpulid polychaete Ficopomatus enigmaticus to those associated with the native oyster Ostrea conchaphila in Elkhorn Slough, a central California estuary. Specifically, we examined utilization of these habitats by different trophic groups and nonnative species. Evidence of greater density or abundance of non-native species in the non-native reef habitat versus native habitat would indicate positive interactions between the non-native ecosystem engineer and associated non-native species, supporting our hypothesis that habitat provision by non-native ecosystem engineers is a mechanism for invasional meltdown.

\section{MATERIALS AND METHODS}

Study system. Elkhorn Slough, a central California estuary (36 $\left.48.6^{\prime} \mathrm{N}, 121^{\circ} 47.1^{\prime} \mathrm{W}\right) 150 \mathrm{~km}$ south of San Francisco Bay, is a primarily soft-sediment environment, with mid- and low intertidal mudflats and a high intertidal pickleweed Salicornia virginica zone. The 1946 opening of Elkhorn Slough's mouth and restoration of flow to previously diked wetlands have greatly enhanced erosion throughout the system, with the greatest impact in the system's main channels. Subtidal banks drop nearly vertically to an unstable shell bed bottom, which shifts with each tidal exchange. Although the subtidal area has hard substrates, the shell beds are too unstable to provide suitable habitat for fouling organisms (K. Heiman pers. obs.) and was not considered in the present study.

There is evidence that the native oyster Ostrea conchaphila was abundant in the slough in the 1930s (MacGinitie 1935); however, oysters are currently found in low densities as clumps (clump defined as congregations of hard substrate-creating organisms covering $<0.5 \mathrm{~m}^{2}$ of the bottom) or as isolated individuals attached to hard surfaces in the intertidal (Hornberger 1991, Heiman 2006). There is only 1 documented intertidal oyster reef (reef defined as congregations of hard substrate-creating organisms covering $>0.5 \mathrm{~m}^{2}$ of the bottom), which covers approximately $7 \mathrm{~m}^{2}$ and rises 10 to $15 \mathrm{~cm}$ off of an anthropogenic rock bed (Site E; Figs. 1 \& 2a). This reef is made up of a loose 
Table 1. Overview of aquatic invasive ecosystem engineers and their effects on associated communities. - /+: negative and positive effects, respectively, on different components of the community observed either within the same study or in different studies; Indet:: indeterminate; $\mathrm{n} / \mathrm{m}$ : not measured or addressed directly by the studies cited

\begin{tabular}{|c|c|c|c|c|c|c|c|c|}
\hline \multirow[t]{2}{*}{ Taxon } & \multirow[t]{2}{*}{ Region } & \multirow[t]{2}{*}{ Habitat } & \multirow{2}{*}{$\begin{array}{l}\text { Experi- } \\
\text { ment }\end{array}$} & \multicolumn{2}{|c|}{ Compared to habitat } & \multicolumn{2}{|c|}{ Response } & \multirow[t]{2}{*}{ Source } \\
\hline & & & & $\begin{array}{l}\text { Native } \\
\text { biogenic }\end{array}$ & $\begin{array}{l}\text { Non- } \\
\text { biogenic }\end{array}$ & $\begin{array}{l}\text { Multi- } \\
\text { species }\end{array}$ & $\begin{array}{l}\text { Non- } \\
\text { natives }\end{array}$ & \\
\hline Caulerpa taxifolia & $\begin{array}{l}\text { French } \\
\text { Mediterranean }\end{array}$ & Shallow subtidal & Yes & Yes & Yes & $-1+$ & $\mathrm{n} / \mathrm{m}$ & 14 \\
\hline $\begin{array}{l}\text { Caulerpa taxifolia/ } \\
\text { C. racemosa }\end{array}$ & Mediterranean & Shallow subtidal & No & No & Yes & $-/+$ & $-/+$ & 1,16 \\
\hline \multicolumn{9}{|l|}{ Grass } \\
\hline Phragmites australis & Atlantic USA & Marsh & No & Yes & No & - & $\mathrm{n} / \mathrm{m}$ & 18,22 \\
\hline $\begin{array}{l}\text { Spartina alterniflora } \times \\
\text { S. foliosa hybrid }\end{array}$ & Pacific USA & Marsh/mudflat & No & Yes & Yes & - & $\mathrm{n} / \mathrm{m}$ & $3,13,15$ \\
\hline Zostera japonica & Pacific USA & Seagrass bed/mudflat & Yes & No & Yes & + & $\mathrm{n} / \mathrm{m}$ & 17 \\
\hline \multicolumn{9}{|l|}{ Bryozoan } \\
\hline $\begin{array}{l}\text { Watersipora subtor- } \\
\text { quata }\end{array}$ & Northern Australia & Hard substrate & Yes & Yes & Yes & + & $\mathrm{n} / \mathrm{m}$ & 8 \\
\hline \multicolumn{9}{|l|}{ Polychaete } \\
\hline Sabella spallanzanii & Southern Australia & Hard substrate & Yes & No & Yes & Indet. & $\mathrm{n} / \mathrm{m}$ & 9 \\
\hline \multicolumn{9}{|l|}{ Snail } \\
\hline Battilaria attramentaria & Pacific USA & Seagrass bed/mudflat & Yes & No & No & + & + & 27 \\
\hline \multicolumn{9}{|l|}{ Mussel } \\
\hline $\begin{array}{l}\text { Mytilus galloprovin- } \\
\text { cialis }\end{array}$ & $\begin{array}{l}\text { South Africa, } \\
\text { Southern Australia }\end{array}$ & Lagoon, seawall & No & Yes & Yes & $-/+$ & $\mathrm{n} / \mathrm{m}$ & 5,20 \\
\hline Dreissena polymorpha & Great Lakes, USA & Hard substrate & Yes & No & Yes & $-/+$ & $\mathrm{n} / \mathrm{m}$ & $10,11,12,19$ \\
\hline $\begin{array}{l}\text { Dreissena polymorpha/ } \\
\text { D. bugensis }\end{array}$ & Great Lakes, USA & Hard substrate & No & No & Yes & + & + & 23,24 \\
\hline Musculista senhousia & $\begin{array}{l}\text { New Zealand, } \\
\text { Pacific USA }\end{array}$ & Mud/sandflat & Yes & No & Yes & $-1+$ & $\mathrm{n} / \mathrm{m}$ & 6,7 \\
\hline $\begin{array}{l}\text { Tunicate } \\
\text { Pyura praeputialis }\end{array}$ & Chile & Rocky shore & No & No & Yes & + & $\mathrm{n} / \mathrm{m}$ & 4 \\
\hline \multicolumn{9}{|c|}{ 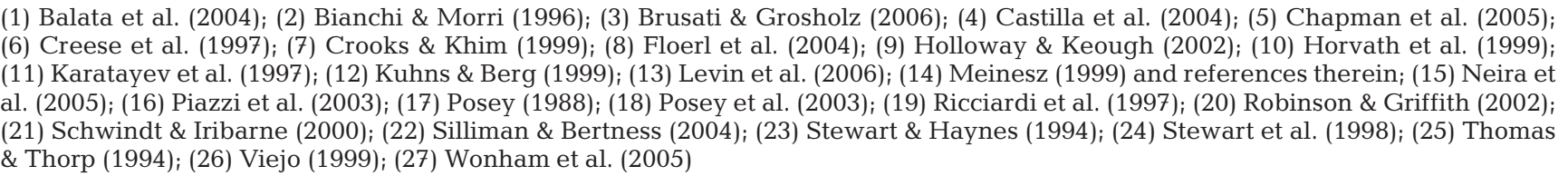 } \\
\hline
\end{tabular}

shell matrix with live oysters primarily in the top $7 \mathrm{~cm}$. Oysters in Elkhorn Slough have an average maximum shell length of $5 \mathrm{~cm}$ and can reach densities of 340 oysters $\mathrm{m}^{-2}$. The native oysters only attach and grow on stable, hard substrates in Elkhorn Slough, including wood, rocks and metal (K. Heiman 2006).

The other major intertidal biogenic hard substrate found in this estuary is the reef-building, non-native serpulid polychaete Ficopomatus enigmaticus, first observed in Elkhorn Slough in 1994 (Wasson et al. 2001). F. enigmaticus individuals live in calcareous tubes, averaging $1.5 \mathrm{~mm}$ in diameter and $90 \mathrm{~mm}$ in length, that are intertwined and cemented to each other forming reef masses up to $1 \mathrm{~m}$ high and $5 \mathrm{~m}$ in diameter. Live worms are found primarily in the top $15 \mathrm{~cm}$ of reef matrix, with densities reaching 60000 ind. $\mathrm{m}^{-2}$ (Heiman 2006; Fig. 2b). Below this living layer, the reef is filled with mud and collapsed tubes. F. enigmaticus requires a small amount of hard substrate for initial colony formation, such as a single shell, rock or bottle (K. Heiman pers. obs.).

In addition to Ficopomatus enigmaticus, 57 marine non-native species have been reported in Elkhorn Slough (Wasson et al. 2001, 2005). Most were introduced as fouling organisms on small boats traveling from San Francisco Bay or with the aquaculture of nonnative Pacific oysters Crassostrea gigas and non-native eastern oysters Crassostrea virginica between the 1920s and 1980s. Non-native oyster spat shipments from Japan and the USA Atlantic coast may have led to the introduction of 38 of the 58 non-native species (Gordon 1996, Wasson et al. 2001). Non-native oyster beds were once located throughout much of the slough, but are now absent; the industry has collapsed, due in part to 


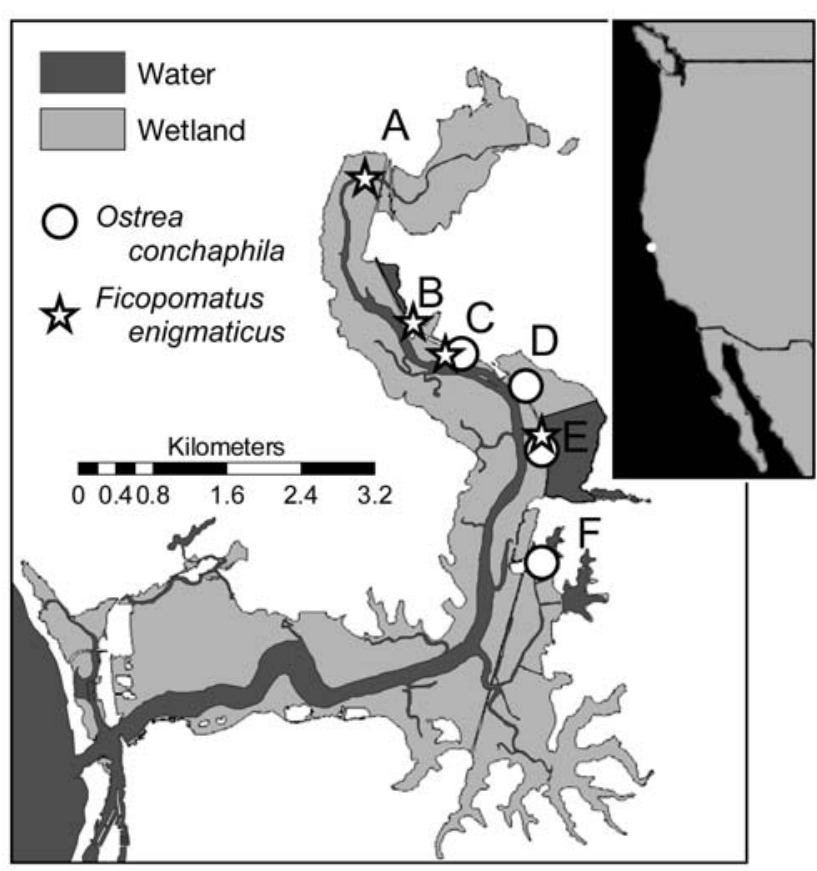

Fig. 1. Elkhorn Slough, a central California estuary $150 \mathrm{~km}$ south of San Francisco Bay. Stars and circles: sampling sites; letter labels: sampling sites from north to south

the non-native oysters' inability to reproduce in cold central California waters (Gordon 1996, Wasson et al. 2001). None of the 57 non-native species in Elkhorn Slough coevolved with F. enigmaticus in Australia.

Field sampling. To compare how native and nonnative biogenic habitats are utilized by benthic invertebrates and whether they host different densities and types of non-native species, we sampled invertebrate communities associated with Ficopomatus enigmaticus and native oysters. We took cores from biogenic habitat created by F. enigmaticus and/or Ostrea conchaphila at 6 intertidal sites between 20 and $-20 \mathrm{~cm}$ MLLW (mean low, low water) between May and July of 2003 (Fig. 1). Sites spanned the distribution of oysters and $F$. enigmaticus in Elkhorn Slough. Both $O$. conchaphila and $F$. enigmaticus were found at 2 of the 6 sites (Sites $\mathrm{C}$ and $\mathrm{E}$ ); only 1 habitat type was present at each of the other 4 sites. At each site, 3 to 10 cores (10 $\mathrm{cm}$ diameter) through the biogenic habitat (from the surface of the reef or clump to the underlying substrate, ranging from 10 to $40 \mathrm{~cm}$ deep) were collected. The number of cores sampled depended on the extent of biogenic habitat at a given site. From Site A for example, where $F$. enigmaticus dominates, we were able to collect 5 samples from the interior and 5 samples from the edge of $F$. enigmaticus reefs. From Site B, 6 samples from $F$. enigmaticus clumps were collected. We collected $4 \mathrm{~F}$. enigmaticus samples and 3 oyster samples from clumps at Site C. At Sites D and F, we were only able to collect 3 oyster samples at each site, due to the limited extent of the biogenic habitat. At Site E, 4 samples from $F$. enigmaticus clumps and 3 samples from the interior and 3 from the edge of the oyster reef were collected.

Samples were sieved through $500 \mu \mathrm{m}$ mesh in the field, preserved in $10 \%$ formaldehyde solution and transferred to $80 \%$ ethanol for storage. All associated organisms were identified to species level and counted under a dissecting microscope. To account for differences in sample volume, we standardized abundance data by 2 different metrics: water displacement volume and weight of each sample's dried biogenic hard substrate. We conducted all subsequent analyses using both metrics, and patterns and significance levels were nearly identical regardless of standardization metric. Here, we present the results for the weight-standardized data.

Statistical analysis. Community composition of associated fauna was compared between habitat types (Ostrea conchaphila or Ficopomatus enigmaticus), and between different habitat sizes within each biogenic habitat type (reef: Site A for F. enigmaticus and Site E for O. Conchaphila; clump: Sites B, C, and E for F. enigmaticus and Sites C, D, and F for O. conchaphila) using multivariate analyses conducted with PRIMER V. 5 (PRIMER-E Ltd). Bray-Curtis dissimilarity (Bray \&
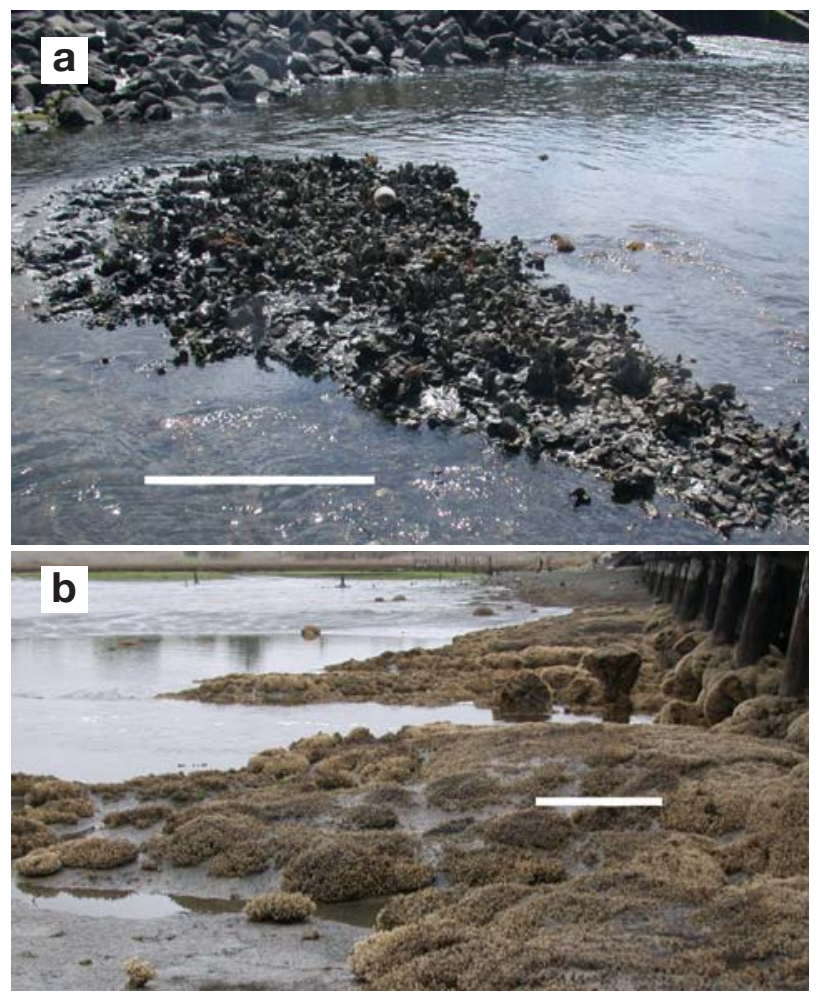

Fig. 2. (a) Ostrea conchaphila oyster reef at Site E and (b) Ficopomatus enigmaticus reef at Site A. Scale bars on photos $=1 \mathrm{~m}$ 
Curtis 1957) between pairs of samples was calculated on square-root transformed abundances to reduce the influence of the most common species on community dissimilarity. Patterns of dissimilarity among samples were visualized using non-metric multidimensional scaling (nMDS) ordinations.

We conducted 1-way analysis of similarity (ANOSIM) on samples from Ficopomatus enigmaticus and Ostrea conchaphila separately, to test if communities associated with a specific biogenic habitat varied with habitat size (i.e. reefs vs. clumps). We tested for significant differences in community structure between habitat types and among sites using 2-way crossed ANOSIMs on samples from the 2 sites with both habitat types

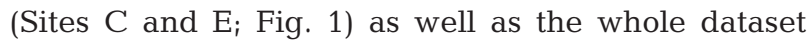
including all sites and samples. ANOSIM produces a test statistic, R, which compares the average rank dissimilarity within and between groups of samples and can be compared across different ANOSIM analyses (Clarke \& Warwick 1994). The greater the R-value for a particular factor (e.g. habitat type), the greater the similarity among samples within a habitat type versus between habitat types (i.e. more variance in community structure is explained by that particular factor, in this case habitat type).

The taxa driving observed differences between groups of samples were identified using similarity percentage (SIMPER) analyses. For species that drive the differences between communities, we conducted ANOVAs to identify if species abundance was significantly different between factors (habitat size, habitat type, or sites). Dunn-Šidák corrections were used to adjust significance levels to account for multiple tests (Sokal \& Rohlf 1995). We also calculated each associated species' density.

In addition to conducting analyses on all taxa, we examined patterns for native and non-native species separately. Species were classified as native to Elkhorn Slough, non-native, or cryptogenic (species of unknown origin, Carlton 1996) based on the following references: Carlton (1979a), Morris et al. (1980), Ruiz et al. (2000), and Wasson et al. (2001). 2-way ANOSIMs (Site $\times$ Habitat type) on the non-native and then the native components of the community were conducted for the 2 sites with both biogenic habitats as well as for the entire dataset. Cryptogenic species $(0.7 \%$ of the total) were omitted from the above analysis.

Trophic groups are related to ecosystem-level functions, such as the transfer of primary production through benthic foodwebs, and may be indicators of habitat characteristics such as food availability (Whitlatch 1980, Pearson 2001). Abundance data were pooled into the following trophic groups: carnivores, detritivores, herbivores, omnivores, and suspension feeders. Some infaunal taxa with flexible feeding strategies can be categorized into more than one trophic group (Levinton 1991). When this occurred, the species' abundance was divided evenly between the trophic groups (Bonsdorff \& Pearson 1999). Only 2 polychaete species (Polydora cornuta and P. socialis, accounting for $0.4 \%$ of the organisms in the present study) had flexible feeding strategies, switching between suspension feeding and surface detritivory with changes in flow speed (Fauchald \& Jumars 1979).

\section{RESULTS}

A total of 25 species were identified in the cores: 12 natives, 10 non-natives, and 3 cryptogenic species (Table 2); 5 species (3 natives, 2 non-natives) were found only in association with Ficopomatus enigmaticus, and 2 species (1 native, 1 non-native) were found only in association with Ostrea conchaphila. Most of the common species, except the oligochaetes Tubificoides brownae and Thalassodrilides gurwitschi, were denser in the non-native $F$. enigmaticus habitat than in the native oyster habitat.

In this study 13 of the 30 species were detritivores, including the numerically abundant introduced amphipod Monocorophium insidiosum, introduced tanaid Sinelobus sp., and native polychaete Cirritulus sp., making detritivores the most numerically abundant (79\% of all organisms) and taxonomically diverse trophic group in the present study (Table 2). There were 4 herbivorous species, including the abundant introduced amphipod Melita nitida, and this group comprised $16.6 \%$ of all organisms. There were 3 omnivorous species, accounting for $3.6 \%$ of the organisms, and 5 carnivorous species, accounting for $0.3 \%$. Suspension feeders were infrequently found $(0.8 \%$ of organisms) and include 2 Polydoria spp. that can switch to detritivory in slower water flow (Fauchald \& Jumars 1979).

The structure of associated communities varied significantly with habitat size in Ficopomatus enigmaticus habitat (10 reef samples compared to 13 clump samples, 1 -way ANOSIM, R =0.721, p=0.001), but not in the Ostrea conchaphila habitat (6 reef samples compared to 9 clump samples, 1 -way ANOSIM, R = 0.041, $\mathrm{p}=0.337$ ). Differences between communities from $F$. enigmaticus reefs and clumps were driven by significantly higher densities of 2 non-native species in clumps, Monocorophium insidiosum (average abundance in reefs $=166 \pm 177$ per $100 \mathrm{~g}$ of biogenic habitat; average abundance in clumps $=503 \pm 344$ per $100 \mathrm{~g}$; ANOVA, $F_{1,18}=5.60, \mathrm{p}=0.0294$ ) and Sinelobus $\mathrm{sp}$. (average abundance in reefs $=0.56 \pm 1.28$ per $100 \mathrm{~g}_{i}$ average abundance in clumps $=50 \pm 39$ per $100 \mathrm{~g}$; ANOVA, $\left.F_{1,18}=95.66, p=0.00001\right)$. In addition, sam- 
Table 2. Species associated with Ostrea conchaphila $(\mathrm{n}=25$ samples) and Ficopomatus enigmaticus $(\mathrm{n}=15$ samples) habitats. Density: ind. per $100 \mathrm{~g}$. Introduction status - N: native, I: introduced, C: cryptogenic. Introduction vector-BW: ballast water; F: ship fouling; O: oyster culture; n/a: not applicable because species is native or cryptogenic; trophic mode-C: carnivore; D: detritivore; O: omnivore; H: herbivore; S: suspension feeder

\begin{tabular}{|c|c|c|c|c|c|c|c|c|c|c|}
\hline \multirow[t]{3}{*}{ Species } & \multirow[t]{3}{*}{ Taxon } & \multicolumn{2}{|c|}{ Introduction } & \multirow{3}{*}{$\begin{array}{l}\text { Trophic } \\
\text { mode }\end{array}$} & \multicolumn{3}{|c|}{ Oyster habitat } & \multicolumn{3}{|c|}{ Tubeworm habitat } \\
\hline & & \multirow[t]{2}{*}{ Status } & \multirow[t]{2}{*}{ Vector } & & \multirow[t]{2}{*}{ Total } & \multicolumn{2}{|c|}{ Density } & \multirow[t]{2}{*}{ Total } & \multicolumn{2}{|c|}{ Density } \\
\hline & & & & & & Mean & $\mathrm{SD}$ & & Mean & $\mathrm{SD}$ \\
\hline Monocorophium insidiosum & Amphipod & I & $\mathrm{F}, \mathrm{O}$ & $\mathrm{D}$ & 755 & 50.3 & 35.0 & 8199 & 328.0 & 326.2 \\
\hline Cirratulus sp. & Polychaete & $\mathrm{C}$ & $\mathrm{n} / \mathrm{a}$ & $\mathrm{D}$ & 114 & 7.6 & 8.5 & 223 & 8.9 & 15.8 \\
\hline Melita nitida & Amphipod & I & F, BW, O & $\mathrm{H}$ & 93 & 6.2 & 3.6 & 2060 & 82.4 & 92.0 \\
\hline Tubificoides brownae & Oligochaete & I & BW, O & $\mathrm{D}$ & 51 & 3.4 & 6.2 & 60 & 2.4 & 2.2 \\
\hline Thalassodrilides gurwitschi & Oligochaete & $\mathrm{N}$ & $\mathrm{n} / \mathrm{a}$ & $\mathrm{D}$ & 49 & 3.3 & 5.3 & 56 & 2.2 & 2.3 \\
\hline Sinelobus sp. & Tanaid & I & $\mathrm{F}, \mathrm{BW}$ & $\mathrm{D}$ & 46 & 3.1 & 2.8 & 658 & 26.3 & 38.4 \\
\hline Pachygrapsus crassipes & Crab & $\mathrm{N}$ & $\mathrm{n} / \mathrm{a}$ & $\mathrm{O}$ & 40 & 2.7 & 2.0 & 66 & 2.6 & 7.0 \\
\hline Cumella vulgaris & Cumacean & $\mathrm{N}$ & $\mathrm{n} / \mathrm{a}$ & $\mathrm{D}$ & 22 & 1.5 & 5.1 & 0 & 0 & 0 \\
\hline Streblospio benedicti & Polychaete & I & $\mathrm{F}, \mathrm{BW}, \mathrm{O}$ & $\mathrm{D}$ & 18 & 1.2 & 2.0 & 80 & 3.2 & 2.1 \\
\hline Hemigrapsus oregonensis & Crab & $\mathrm{N}$ & $\mathrm{n} / \mathrm{a}$ & $\mathrm{O}$ & 18 & 1.2 & 1.1 & 291 & 11.6 & 11.7 \\
\hline Boccardia proboscidea & Polychaete & $\mathrm{N}$ & $\mathrm{n} / \mathrm{a}$ & $\mathrm{D}$ & 13 & 0.9 & 1.5 & 13 & 0.5 & 1.1 \\
\hline Grandidierella japonica & Amphipod & $\mathrm{I}$ & $\mathrm{F}, \mathrm{BW}, \mathrm{O}$ & $\mathrm{H}$ & 7 & 0.5 & 0.6 & 45 & 1.8 & 4.5 \\
\hline Boccardia hamata & Polychaete & $\mathrm{N}$ & $\mathrm{n} / \mathrm{a}$ & $\mathrm{D}$ & 6 & 0.4 & 0.5 & 17 & 0.7 & 1.1 \\
\hline Heteromastus filiformis & Polychaete & I & $\mathrm{BW}, \mathrm{O}$ & $\mathrm{D}$ & 6 & 0.4 & 0.5 & 73 & 2.9 & 3.3 \\
\hline Polydora socialis & Polychaete & $\mathrm{N}$ & $\mathrm{n} / \mathrm{a}$ & $\mathrm{D} / \mathrm{S}$ & 6 & 0.4 & 2.1 & 48 & 1.9 & 2.1 \\
\hline Leptochelia sp. & Tanaid & $\mathrm{C}$ & $\mathrm{n} / \mathrm{a}$ & $\mathrm{O}$ & 6 & 0.4 & 0.6 & 68 & 2.7 & 9.3 \\
\hline Phoxichilidium femoratus & Pycnogonid & $\mathrm{N}$ & $\mathrm{n} / \mathrm{a}$ & $\mathrm{C}$ & 6 & 0.4 & 1.0 & 13 & 0.51 & 2.9 \\
\hline Capitella sp. & Polychaete & $\mathrm{C}$ & $\mathrm{n} / \mathrm{a}$ & $\mathrm{D}$ & 5 & 0.3 & 0.6 & 16 & 0.6 & 1.0 \\
\hline Eteone californica & Polychaete & $\mathrm{N}$ & $\mathrm{n} / \mathrm{a}$ & $\mathrm{C}$ & 1 & 0.1 & 0.2 & 15 & 0.6 & 0.9 \\
\hline Carcinus maenas & Crab & $\mathrm{I}$ & BW, O & $\mathrm{C}$ & 1 & 0.1 & 0.2 & 0 & 0 & 0 \\
\hline Polydoria cornuta & Polychaete & I & $\mathrm{F}, \mathrm{BW}, \mathrm{O}$ & $\mathrm{D} / \mathrm{S}$ & 0 & 0 & 0 & 3 & 0.1 & 0.3 \\
\hline Nebalia gerkenae & Sea flea & $\mathrm{N}$ & $\mathrm{n} / \mathrm{a}$ & $\mathrm{S}$ & 0 & 0 & 0 & 8 & 0.3 & 1.2 \\
\hline Sphaeroma quoianum & Isopod & I & $\mathrm{F}$ & $\mathrm{S}$ & 0 & 0 & 0 & 48 & 1.9 & 7.9 \\
\hline Halosydna brevisetosa & Polychaete & $\mathrm{N}$ & $\mathrm{n} / \mathrm{a}$ & $\mathrm{C}$ & 0 & 0 & 0 & 2 & 0.1 & 0.2 \\
\hline Platynereis bicanaliculata & Polychaete & $\mathrm{N}$ & $\mathrm{n} / \mathrm{a}$ & G & 0 & 0 & 0 & 3 & 0.1 & 0.7 \\
\hline Total & & & & & 1264 & & & 12065 & & \\
\hline
\end{tabular}

ples collected from the interior of $F$. enigmaticus reefs contained significantly lower densities of associated organisms compared to samples from the edge of reefs (average abundance in reef interior $=61 \pm 67$ per $100 \mathrm{~g}$; average abundance in reef edge $=535 \pm 152$ per $100 \mathrm{~g}$; ANOVA, $F_{1,18}=40.79, \mathrm{p}=0.0002$ ).

At the 2 sites with both habitat types (Sites $\mathrm{C}$ and $\mathrm{E}_{i}$ Fig. 1), communities exhibited significant separation between sites when all species were included in the analyses (2-way ANOSIM, R $=0.5$, $p=0.002$; Fig. 3a), with further clustering evident according to the biogenic habitat type (Ficopomatus vs. Ostrea; 2-way ANOSIM, R = 0.567, p = 0.005; Fig. 3a). When only native species were considered, more of the variation in community structure appeared to be driven by differences between sampling sites (2-way ANOSIM, site: $\mathrm{R}=0.591, \mathrm{p}=0.001$; habitat type: $R=0.214, p=0.024$, nonsignificant after Dunn-Šidák correction;
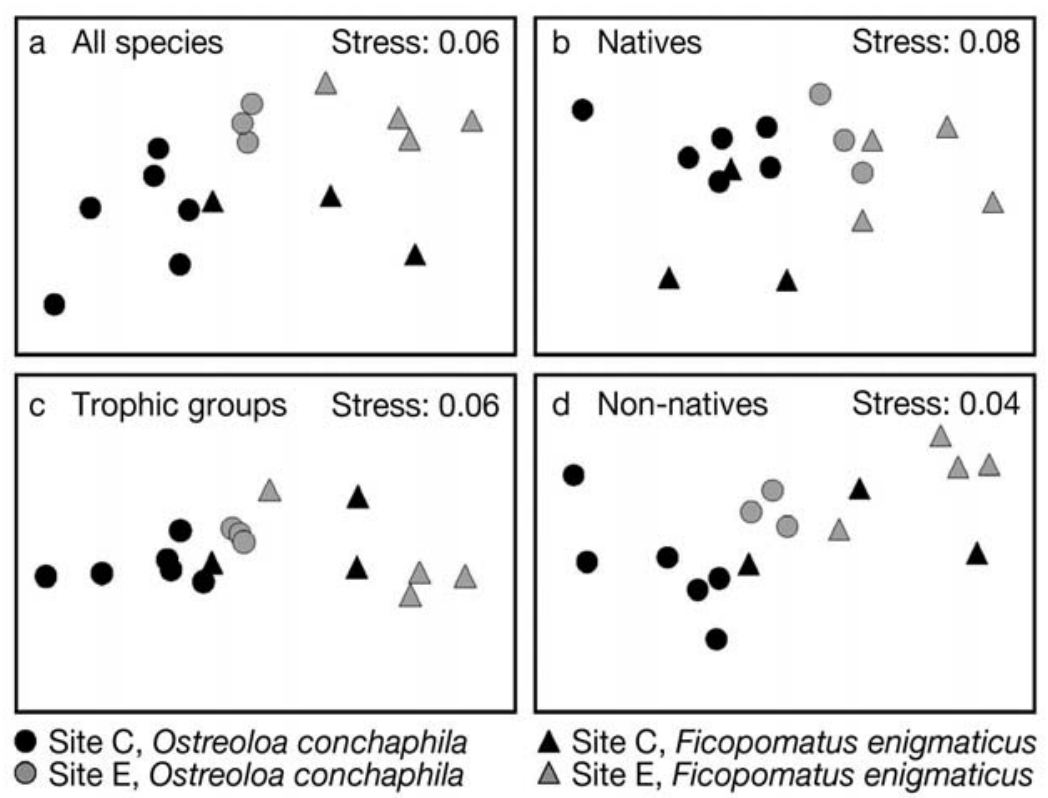

Fig. 3. nMDS ordinations of infaunal community structure in samples from Sites C and E (the sites with both Ficopomatus enigmaticus and Ostrea conchaphila biogenic habitats) based on square-root transformed Bray-Curtis dissimilarities. (a) Bray-Curtis dissimilarities calculated with all species, (b) with only native species, (c) trophic groups, and (d) only non-native species 
Fig. 3b). In contrast, more of the variation in community structure was associated with habitat type for nonnative species (2-way ANOSIM, site: $\mathrm{R}=0.414, \mathrm{p}=$ 0.026, non-significant after Dunn-Šidák correction; habitat type: $\mathrm{R}=0.645, \mathrm{p}=0.006$; Fig. 3d) and for trophic groups (2-way ANOSIM, site: $\mathrm{R}=0.322$, $\mathrm{p}=$ 0.057; habitat type: $\mathrm{R}=0.653, \mathrm{p}=0.004$; Fig. 3c).

The same pattern was observed for natives, nonnatives, and the whole community, whether we used the conservative analysis of only samples from the 2 sites with both biogenic habitat types (Fig. $4 \mathrm{a}_{\text {; }} \mathrm{R}$ and $\mathrm{p}$ values as reported above), or whether we expanded the analysis to include all samples from all sites (Fig. 4b). When all sites and all species were included, biogenic habitat type and site explained similar amounts of the variation among samples (2-way ANOSIM, site: $\mathrm{R}=$ 0.487, $\mathrm{p}=0.001$; habitat type: $\mathrm{R}=0.514, \mathrm{p}=0.001$; Fig. 4b). More of the variation in native species' distributions was explained by site than habitat type (2-way ANOSIM, site: $\mathrm{R}=0.705, \mathrm{p}=0.001$; habitat type: $\mathrm{R}=$ 0.377, $p=0.01$; Fig. 4b), whereas the opposite was true for non-native species (2-way ANOSIM, site: $\mathrm{R}=0.319$, $\mathrm{p}=0.005$; habitat type: $\mathrm{R}=0.475, \mathrm{p}=0.006$ ) and trophic groups (2-way ANOSIM, site: $\mathrm{R}=0.229, \mathrm{p}=0.016$; habitat type: $\mathrm{R}=0.594, \mathrm{p}=0.008$; Fig. $4 \mathrm{~b}$ ).

Variation in communities between habitats was driven by higher abundances of 5 species in the non-
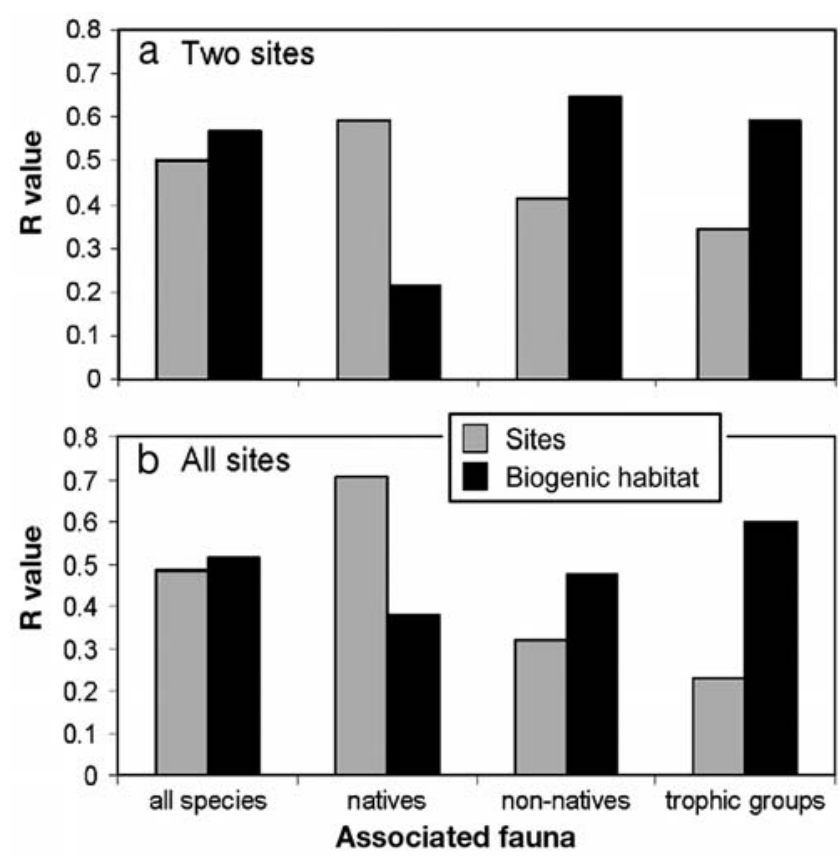

Fig. 4. Average dissimilarity between sites and biogenic habitats for infaunal community components: all species, only native species, only introduced species, and trophic groups. Rvalues from ANOSIM analysis of square-root transformed Bray-Curtis dissimilarities of specified community components in: (a) samples from Sites C and E and (b) all samples from all sites native habitat: 3 non-natives, the amphipods Monocorophium insidiosum, Melita nitida, and the tanaid Sinelobus sp., and 2 natives, the polychaete Cirratulus sp. and the crab Hemigrapsus oregonensis (Table 3). The trophic groups driving community patterns were detritivores and omnivores, respectively explaining 45.5 and $25 \%$ of the differences between communities in the 2 different habitat types (Table 3). All of these species and trophic groups were more abundant in Ficopomatus enigmaticus samples than in Ostrea conchaphila, some as much as 16 times more abundant. However, when relative proportion of the community associated with each habitat type was calculated for each species and trophic group, only the most abundant species ( $M$. insidiosum, and $M$. nitida) and trophic group (detritivores) were more common in F. enigmaticus habitats (Table 3).

\section{DISCUSSION}

Ficopomatus enigmaticus and Ostrea conchaphila occupy similar tidal elevations and provide hard structure in predominantly soft-sediment environments, but support significantly different communities. Our study provides evidence for positive interactions between the non-native $F$. enigmaticus and other non-native species within Elkhorn Slough. Denser associations of non-native species were seen in the non-native $F$. enigmaticus habitat as compared to the native oyster habitat. In contrast, variation in the native component of associated communities was explained more by site than by biogenic habitat type. We suggest that the provision of a complex structural habitat by $F$. enigmaticus may be a mechanism for invasional meltdown within this estuary. The high abundance of non-natives may indicate that their population persistence and growth in this system has been facilitated by the availability of structural habitat provided by F. enigmaticus. None of the associated species from the present study are exclusively found in the $F$. enigmaticus or oyster habitats, but their abundance within the introduced habitat is, in general, at least 3 times greater than in most other hard and soft habitats within Elkhorn Slough examined by the authors in related studies (Heiman 2006).

The high abundance of detritivores in both habitats, but especially within Ficopomatus enigmaticus reefs, suggests that the communities of associated organisms rely on accumulation of organic matter within these habitats for food. While we did not quantify the amount of mud in each sample, we did observe that F. enigmaticus samples contained far more mud than native oyster samples. The greater amount of mud in the $F$. enigmaticus habitat may account for the difference in the abundance of detritivores between the 2 habitats. 
Table 3. Species and trophic groups contributing to most of the variation between communities associated with the native oyster Ostrea conchaphila ( $\mathrm{n}=23$ samples) and with the non-native tubeworm Ficopomatus enigmaticus ( $\mathrm{n}=15$ samples). Results reported from SIMPER analysis of all samples across all sites

\begin{tabular}{|c|c|c|c|c|c|c|c|}
\hline & \multicolumn{3}{|c|}{$\longrightarrow$ Oyster habitat -} & \multicolumn{3}{|c|}{ Tubeworm habitat -} & \multirow{3}{*}{$\begin{array}{c}\text { Contribution } \\
\text { to dissimilarity } \\
(\%)\end{array}$} \\
\hline & Density (in & er $100 \mathrm{~g}$ ) & Proportion & Density (inc & per $100 \mathrm{~g})$ & Proportion & \\
\hline & Mean & $\mathrm{SD}$ & $(\%)$ & Mean & $\mathrm{SD}$ & $(\%)$ & \\
\hline \multicolumn{8}{|l|}{ Species } \\
\hline Monocorophium insidiosum ${ }^{\mathrm{a}}$ & 43.8 & 37.9 & 33.8 & 356.5 & 326.3 & 65.7 & 27.1 \\
\hline Melita nitida ${ }^{\mathrm{a}}$ & 5.4 & 3.6 & 4.1 & 89.6 & 92.0 & 16.5 & 14.8 \\
\hline Sinelobus sp. ${ }^{\mathrm{a}}$ & 2.7 & 2.8 & 2.1 & 28.6 & 38.4 & 5.3 & 8 \\
\hline Hemigrapsus oregonensis & 0.8 & 1.0 & 0.6 & 12.6 & 11.7 & 2.3 & 6.9 \\
\hline Ciratulus sp. & 7.4 & 9.0 & 5.7 & 9.7 & 15.8 & 1.8 & 6.1 \\
\hline \multicolumn{8}{|l|}{ Trophic groups } \\
\hline Detritivores & 64.2 & 41.9 & 51.7 & 409.7 & 354.0 & 82.7 & 45.5 \\
\hline Omnivores & 3.4 & 2.2 & 2.7 & 18.6 & 15.9 & 3.8 & 25 \\
\hline Herbivores & 9.7 & 9.0 & 8.1 & 15.7 & 17.4 & 2.9 & 10.2 \\
\hline Suspension feeders & 0.2 & 0.3 & 0.2 & 5.26 & 16.0 & 1.1 & 6.8 \\
\hline${ }^{a}$ Non-native species & & & & & & & \\
\hline
\end{tabular}

Further study using different sampling techniques with the capacity to capture and quantify the mud associated with each habitat is needed to test this observational correlation.

Abundances of associated fauna may be greater in Ficopomatus enigmaticus habitats as compared to oyster habitat, because the non-native reef's complex, 3-dimensional structure provides refuge from predation, more habitat or living space, and/or altered water flows, which may enhance food availability for associated organisms. Matsumasa (1994) found that the physical structure of biogenic substrates directly determined the identity of the most abundant associated crustaceans. Increases in associated fauna in experimental manipulations of the invasive bivalves Musculista senhousia and Dreissena polymorpha have also been attributed to structural complexity of the biogenic habitats (Crooks \& Khim 1999, Horvath et al. 1999). The greater structural complexity of $F$. enigmaticus reefs, formed by the intertwining small calcareous tubes, may explain why most of the species examined were more abundant in the invasive reefs than in the native oyster habitat, even after standardizing by the weight or volume of each sample's biogenic material. The availability of crevices as refuges or living space for associated organisms may also explain the greater faunal abundances found at the edges compared to the centers of $F$. enigmaticus reefs, where crevices are filled with anoxic mud (K. Heiman unpubl. data). In contrast, the loose shell matrix throughout the oyster beds may explain the lack of community variation between the edges and center of the Ostrea conchaphila reefs. The great abundance of associated nonnative species with the invasive reefs is likely not a function of the habitat being non-native per se, but rather that $F$. enigmaticus provides a new and different structurally complex habitat in this mudflat ecosystem. Experiments exploring the role of habitat complexity are needed to directly test if this is the facilitation mechanism at work.

Sites (i.e. location) within Elkhorn Slough explained a greater proportion of the variation in the native component of reef-associated invertebrate communities than biogenic habitat type, whereas the opposite was true for non-native species. Many of the native species found in Elkhorn Slough evolved in soft-sediment habitats, where they likely developed adaptations to specific environmental conditions such as sediment grain size, salinity, and oxygen content of the sediments and of the water. Different sites within Elkhorn Slough support different sediment, salinity and temperature conditions, potentially explaining why native communities exhibit significant between-site variation. Conversely, many non-native species have broad environmental tolerances for salinity (Ruiz et al. 2000), and possibly for temperature and oxygen levels, allowing them to colonize opportunistically a broad range of sites. However, non-native species may have specific microhabitat preferences within these sites. For example, Monocorophium insidiosum, a tube-dwelling amphipod, can tolerate wide salinity ranges (Kevrekidis 2004), but is often found in higher abundance on complex biogenic structures such as Ficopomatus enigmaticus, even though it can exist in mudflats (Carlton 1979b, Heiman 2006).

The suspension-feeding Ficopomatus enigmaticus likely plays an important role in the transfer of pelagic production to the benthos. The high abundance of detritivores within the non-native reefs may be the result of enhanced local availability of organic matter in the sediments through sediment entrapment and pseudofeces accumulation. Similar results have been 
observed in a number of other invasive aquatic ecosystem engineers, such as the mussels Dreissena polymorpha and Musculista senhousia (Stewart \& Haynes 1994, Crooks \& Khim 1999). These abundant associated species may or may not provide food resources for higher trophic groups, depending on how much protection from predators is provided by the biogenic habitat. This study did not identify many carnivores associated with either the native or non-native biogenic habitats, suggesting that smaller predators are not disproportionally attracted to the abundant prey in the biogenic habitats (Table 2). However, fish and shrimp forage above submerged $F$. enigmaticus reefs (K. Heiman pers. obs.), suggesting that some predators can access either the associated communities or F. enigmaticus itself. Further foodweb studies are required to address this possibility.

There are multiple ways habitat-forming, non-native marine invertebrates can impact estuarine ecosystems. In this study, we explored the role of non-native species in creating habitat for native and non-native benthic communities. Other ecosystem-level effects of the introduction of the suspension-feeding Ficopomatus enigmaticus, such as alteration of water clarity and effects on phytoplankton communities, may also be important (Davies et al. 1989). F. enigmaticus and other non-native species that form biogenic habitat, especially those that suspension feed, may be strongly interacting species in their new environments, with cascading effects on ecosystem structure and function (Heiman 2005, Soulé et al. 2005). Because F. enigmaticus has the potential to affect multiple ecosystem processes, it is a prime target for directed management efforts. Our results suggest that focusing research, control, and eradication efforts on strongly interacting invasive species such as F. enigmaticus may additionally result in the control of a suite of other non-native species.

Acknowledgements. We thank J. Watanabe, A. Shelton, K. Wasson, M. O'Donnell, L. Hunt, A. Haydeman, P. Slattery, J. Oliver, F. Sommer, C. Kappel, L. Miller, C. Reilly, M. Denny, G. Somero, R. Goldman Martone, J. Pearse, J. Carlton and A. Clark for their assistance in the field, help with species identification, and insightful comments on this manuscript. The comments of 3 anonymous reviewers greatly improved the manuscript. This work was funded by a National Estuarine Research Reserve Graduate Student Fellowship and an Environmental Protection Agency-Science To Achieve Results Graduate Fellowship awarded to K.W.H., and a Stanford University McGee Grant in Earth Sciences awarded to N.V.

\section{LITERATURE CITED}

Balata D, Piazzi L, Cinelli F (2004) A comparison among assemblages in areas invaded by Caulerpa taxifolia and $C$. racemosa on a subtidal Mediterranean rocky bottom. PSZN I: Mar Ecol 25:1-13
Bianchi CN, Morri C (1996) Ficopomatus 'reefs' in the Po River Delta (northern Adriatic): their construction dynamics, biology, and influences on the brackens-water biota. PSZN I: Mar Ecol 17:51-66

Bonsdorff E, Pearson TH (1999) Variation in the sublittoral macrozoobenthos of the Baltic Sea along environmental gradients: a functional-group approach. Aust J Ecol 24: 312-326

Bray JR, Curtis T (1957) An ordination of the upland forest communities of southern Wisconsin. Ecol Monogr 27: 325-349

Brusati ED, Grosholz ED (2006) Native and introduced ecosystem engineers produce contrasting effects of estuarine infaunal communities. Biol Invasions 8:683-695

Carlton JT (1979a) History, biogeography, and ecology of the introduced marine and estuarine invertebrates of the Pacific Coast of North America. PhD dissertation, University of California, Davis, CA

Carlton JT (1979b) Introduced invertebrates of San Francisco Bay. In: Conomos TJ (ed) San Francisco Bay: the urbanized estuary. Pacific Division of the American Association for the Advancement of Science, San Francisco, CA, p 427-444

Carlton JT (1996) Biological invasions and cryptogenic species. Ecology 77:1653-1665

> Castilla JC, Lagos NA, Cerda M (2004) Marine ecosystem engineering by the alien ascidian Pyura praeputialis on a mid-intertidal rocky shore. Mar Ecol Prog Ser 268: $119-130$

Chapman MG, People J, Blockley D (2005) Intertidal assemblages associated with natural Corallina turf and invasive mussel beds. Biodivers Conserv 14:1761-1776

Clarke KR, Warwick RM (1994) Change in marine communities: an approach to statistical analysis and interpretation. Natural Environment Research Council, Plymouth Marine Laboratories

Creese R, Hooker S, De Luca S, Wharton Y (1997) Ecology and environmental impact of Musculista senhousia (Mollusca: Bivalvia: Mytilidae) in Tamaki Estuary, Auckland, New Zealand. N Z J Mar Freshw Res 31:225-236

Crooks JA, Khim HS (1999) Architectural vs. biological effects of a habitat-altering, exotic mussel, Musculista senhousia. J Exp Mar Biol Ecol 240:53-75

Davis BR, Stuart V, De Villiers M (1989) The filtration activity of a serpulid polychaete population Ficopomatus enigmaticus (Fauval) and its effects on water quality in a coastal marina. Estuar Coast Shelf Sci 29:613-620

> Davis MA, Pelsor M (2001) Experimental support for a resource-based mechanistic model of invasibility. Ecol Lett 4:421-428

Davis MA, Grime JP, Thompson K (2000) Fluctuating resources in plant communities: a general theory of invasibility. J Ecol 88:528-534

Dayton PK (1972) Toward an understanding of community resilience and the potential effects of enrichments to the benthos at McMurdo Sound, Antarctica. In: Parker BC (ed) Proceedings of the colloquium on conservation problems in Antarctica. Allen Press, Lawrence, KS, p 81-96

Ellison AM, Bank MS, Clinton BD, Colburn EA and others (2005) Loss of foundation species: consequences for the structure and dynamics of forested ecosystems. Front Ecol Environ 3:479-486

Fauchald K, Jumars PA (1979) The diet of worms: A study of polychaete feeding guilds. Oceanogr Mar Biol Annu Rev 17:193-284

Floerl O, Pool TK, Inglis GJ (2004) Positive interactions between nonindigenous species facilitate transport by human vectors. Ecol Appl 14:1724-1736 
Gordon BP (1996) Monterey Bay: natural history and cultural imprints, 3rd edn. Boxwood Press, Pacific Grove, CA

Heiman KW (2005) Strongly interacting nonindigenous species. Bioscience 55:548

Heiman KW (2006) Hard substrate as a limiting resource structuring invaded communities within a central California estuary. $\mathrm{PhD}$ dissertation, Stanford University, CA

Holloway MG, Keough MJ (2002) Effects of an introduced polychaete, Sabella spallanzanii, on the development of epifaunal assemblages. Mar Ecol Prog Ser 236:137-154

Hornberger M (1991) Paleoenvironment of Elkhorn Slough and surrounding wetland habitats: a geological study using an ecological approach. MS dissertation, San Jose State University, CA

Horvath TG, Martin KM, Lamberti GA (1999) Effect of zebra mussels, Dreissena polymorpha, on macroinvertebrates in a lake-outlet stream. Am Midl Nat 142:340-347

Jones CG, Lawton JH, Shachak M (1994) Organisms as ecosystem engineers. Oikos 69:373-386

Jones CG, Lawton JH, Shachak M (1997) Positive and negative effects of organisms as physical ecosystem engineers. Ecology 78:1946-1957

Kappel CV (2005) Losing pieces of the puzzle: threats to marine, estuarine, and diadromous species. Front Ecol Environ 3:275-282

Karatayev AY, Burlakova LE, Padilla DK (1997) The effects of Dreissena polymorpha (Pallas) invasion on aquatic communities in eastern Europe. J Shellfish Res 16:187-203

Kevrekidis T (2004) Population dynamics, growth and reproduction of Corophium insidiosum (Crustacea: Amphipoda) at low salinities in Monolimni lagoon (Evros Delta, North Aegean Sea). Hydrobiologia 522:117-132

Kuhns LA, Berg MB (1999) Benthic invertebrate community responses to round goby (Neogobius melanostomus) and zebra mussel (Dreissena polymorpha) invasion in southern Lake Michigan. J Gt Lakes Res 25:910-917

Levin LA, Neira C, Grosholz ED (2006) Invasive cordgrass modifies wetland trophic function. Ecology 87:419-432

Levinton JS (1991) Variable feeding behavior in three species of Macoma (Bivalvia: Tellinidae) as a response to water flow and sediment transport. Mar Biol 110:375-383

MacGinitie GE (1935) Ecological aspects of a California marine estuary. Am Midl Nat 16:629-765

Matsumasa M (1994) Effect of secondary substrate on associated small crustaceans in a brackish lagoon. J Exp Mar Biol Ecol 176:245-256

Meinesz A (1999) Killer algae. University of Chicago Press, Chicago, IL

Morris RH, Abbott DP, Haderlie EC (1980) Intertidal invertebrates of California. Stanford University Press, Stanford, CA

Neira C, Levin LA, Grosholz ED (2005) Benthic macrofaunal communities of three sites in San Francisco Bay invaded by hybrid Spartina, with comparison to uninvaded habitats. Mar Ecol Prog Ser 292:111-126

Pearson TH (2001) Functional group ecology in soft-sediment marine benthos: the role of bioturbation. Oceanogr Mar Biol Annu Rev 39:233-267

Piazzi L, Balata D, Cecchi E, Cinelli F (2003) Co-occurrence of Caulerpa taxifolia and C. racemosa in the Mediterranean Sea: interspecific interactions and influence on native macroalgal assemblages. Cryptogam, Algol 24:233-243

Posey MH (1988) Community changes associated with the spread of an introduced seagrass Zostera japonica. Ecology 69:974-983

Initial editorial responsibility: Howard Browman, Storebø, Norway (until Nov. 5, 2007); Final editorial responsibility: Matthias Seaman, Oldendorf/Luhe, Germany
Posey MH, Alphin TD, Meyer DL, Johnson JM (2003) Benthic communities of common reed Phragmites australis and marsh cordgrass Spartina alterniflora marshes in Chesapeake Bay. Mar Ecol Prog Ser 261:51-61

Ricciardi A, Whoriskey FG, Rasmussen JB (1997) The role of the zebra mussel (Dreissena polymorpha) in structuring macroinvertebrate communities on hard substrata. Can J Fish Aquat Sci 54:2596-2608

Robinson TB, Griffiths CL (2002) Invasion of Langebaan Lagoon, South Africa, by Mytilus galloprovincialis: effects on natural communities. Afr Zool 37:151-158

Ruiz GM, Fofonoff PW, Carlton JT, Wonham MJ, Hines AH (2000) Invasion of coastal marine communities in North America: apparent patterns, processes, and biases. Annu Rev Ecol Syst 31:481-531

Schwindt E, Iribarne OO (2000) Settlement sites, survival and effects on benthos of an introduced reef-building polychaete in a SW Atlantic coastal lagoon. Bull Mar Sci 67:73-82

Silliman BR, Bertness MD (2004) Shoreline development drives invasion of Phragmites australis and the loss of plant diversity on New England salt marshes. Conserv Biol 18:1424-1434

Simberloff D, Von Holle B (1999) Positive interactions of nonindigenous species: invasional meltdown? Biol Invasions $1: 21-32$

Sokal RR, Rohlf JF (1995) Biometry, 3rd edn. W. H. Freeman and Company, New York

Soulé ME, Estes JA, Miller B, Honnold DL (2005) Strongly interacting species: conservation policy, management, and ethics. Bioscience 55:168-176

Stewart TW, Haynes JM (1994) Benthic macroinvertebrate communities of southwestern Lake Ontario following invasion of Dreissena. J Gt Lakes Res 20:479-493

Stewart TW, Miner JG, Lowe RL (1998) Macroinvertebrate communities on hard substrates in western Lake Erie: structuring effects of Dreissena. J Gt Lakes Res 24: 868-879

Thomas NS, Thorp CH (1994) Cyclical changes in the fauna associated with tube aggregates of Ficopomatus enigmaticus (Fauvel). In: Dauvin JC, Laubier L, Reish DJ (eds) Actes de la 4ème Conférence internationale des Polychètes. Memoires du Museum National d'histoiro Naturelle, Angers, France, p 575-584

Viejo RM (1999) Mobile epifauna inhabiting the invasive Sargassum muticum and two local seaweeds in northern Spain. Aquat Bot 64:131-149

Wasson K, Zabin JC, Bedinger L, Diaz MC, Pearse JS (2001) Biological invasions of estuaries without international shipping: the importance of intraregional transport. Biol Conserv 102:143-153

Wasson K, Fenn K, Pearse JS (2005) Habitat bias in marine invasions of Central California. Biol Invasions 7:935-948

Whitlatch RB (1980) Patterns of resource utilization and coexistence in marine intertidal deposit-feeding communities. J Mar Res 38:743-765

Wilcove DS, Rothstein D, Dubow J, Phillips A, Losos E (1998) Quantifying threats to imperiled species in the United States. Bioscience 48:607-615

Wonham MJ, Carlton JT (2005) Trends in marine biological invasions at local and regional scales: the Northeast Pacific Ocean as a model system. Biol Invasions 7:369-392

Wonham MJ, O'Conner M, Harley CDG (2005) Positive effects of a dominant invader on introduced and native mudflat species. Mar Ecol Prog Ser 289:109-116

Submitted: October 11, 2007; Accepted: January 28, 2008

Proofs received from author(s): February 28, 2008 